\title{
Herbaceous Understory Indicators of Post-Harvest Recovery in Coast Redwood (Sequoia sempervirens) Forests
}

\author{
Will Russell \\ Department of Environmental Studies, One Washington Square, San José, CA, USA \\ Email: will.russell@sjsu.edu
}

How to cite this paper: Russell, W. (2020). Herbaceous Understory Indicators of PostHarvest Recovery in Coast Redwood (Sequoia sempervirens) Forests. Open Journal of Forestry, 10, 204-216.

https://doi.org/10.4236/ojf.2020.102014

Received: December 31, 2019

Accepted: March 6, 2020

Published: March 9, 2020

Copyright $\odot 2020$ by author(s) and Scientific Research Publishing Inc. This work is licensed under the Creative Commons Attribution International License (CC BY 4.0).

http://creativecommons.org/licenses/by/4.0/

\begin{abstract}
Assessment of forest recovery following disturbance is enhanced by the use of biological indicators. One such indicator, the abundance of understory species, was examined in coast redwood (Sequoia sempervirens) forests using non-metric multiple dimensional scaling (NMDS) and indicator species analysis (ISA). Randomly distributed $10 \mathrm{~m}$ diameter circular plots were employed to record the abundance of all understory species across three treatments: actively managed ( 0 - 45 years since harvest); mature second-growth ( $\sim 80$ - 120 years since harvest); and unharvested old-growth stands. NMDS with perMANOVA analysis signified separation between treatments with the shade tolerant herbaceous species Trillium ovatum, Viola sempervirens, and Oxalis oregana positively correlated with mature second-growth and old-growth treatments. ISA supported the inclusion of T. ovatum, with the addition of Prosartes hookerii, as indicators of mature second-growth and old-growth. Both NMDS and ISA specified associations for Ceanothus thyrsiflorus and Stachys bullata with actively-managed stands. Occurrence of non-natives was low across treatments, though significantly higher on actively managed stands, with the shade intolerant invasive plants, Cortaderia sp. and Myosotis latifolia, occurring exclusively in actively-managed sites.
\end{abstract}

\section{Keywords}

Indicator Species, Coast Redwood, Timber Harvest, Old-Growth, Trillium ovatum

\section{Introduction}

Biological indicators have been used to assess health and recovery following dis- 
turbance in a variety of ecosystems (Andersen \& Sparling, 1997; Coelho et al., 2009; Egli, 2011; Pander \& Geist, 2013). Such indicators are identified based on their association with a specific forest type, and dependence on inherent habitat conditions (Mcclelland \& Mcclelland, 1999; Drever et al., 2008; Egli, 2011). Reestablishment of herbaceous plants may provide an effective indicator of recovery following logging in coast redwood (Sequoia sempervirens) forests, where understory species are dependent on low levels of disturbance and closed canopy conditions (Runkle, 1982).

The canopy of coast redwood forests is rarely disturbed by natural stand-replacing events, and provides the conditions necessary for dependent herbaceous species to thrive (Van Pelt \& Franklin, 2000). The coast redwood understory is dominated by shade-tolerant, moisture dependent species, adapted to a regime of low level infrequent disturbance (Barbour et al., 2001; Busing \& Fujimori, 2009; Limm et al., 2009). A gap mosaic, created by occasional tree falls, provides conditions favorable to a few opportunistic generalists, but these gaps close quickly under natural conditions with sub-canopy associates and clonal regeneration from $S$. sempervirens restoring the canopy (Noss, 1999). A general lack of natural stand-replacing events in this forest type has resulted in a suite of associated species poorly adapted to the frequent, and often intense, disturbances created by industrial timber-harvest practices. In addition, the use of herbaceous understory species as indicators is an attractive option, as much of the plant diversity in coast redwood forests is found in the understory, and many of these species are known to be sensitive to logging (Gilliam, 2007; Loya \& Jules, 2008; Russell \& Michels, 2010).

While metrics based on total understory cover and richness are often reported in the literature, these measures are fairly consistent between old-growth and second-growth stands; and thus are not as effective as individual understory species metrics which vary significantly based on individual physiological tolerances (Loya \& Jules, 2008; Russell \& Michels, 2010; Keyes \& Teraoka, 2014). Coast redwood associated understory species such as Asarum coudatum (wild ginger), Lysimachia latifolia (pacific star flower), Oxalis oregana (redwood sorrel), Polystichum munitum (western sword fern), Prosartes hookeri (hooker's fairybells), Trillium ovatum (pacific trillium), and Viola sempervirens (redwood violet) are known to be sensitive to timber harvest, and their abundance has been correlated to forest metrics such as tree density, canopy cover, and tree size (Meier et al., 1995; Gilliam, 2007; Loya \& Jules, 2008; Russell, 2009; Russell \& Michels, 2010; Russell et al., 2014).

Trillium ovatum, a rhizomaceuous perennial herb (Case \& Case, 1997), is of particular interest as an indicator species as it is long lived and sensitive to timber management in coast redwood as well as other forest types (Kirschbaum \& Anacker, 2005; Keyes \& Teraoka, 2014). T. ovatum has been shown to grow preferentially in old-growth, as compared to managed, Douglas-fir forests in Oregon (Jules \& Rathcke, 1999; Kahmen \& Jules, 2005), and other members of 
the genus have been found to have similar relationships to logging in other forest types (Jenkins \& Webster, 2009). In the coast redwood forest, greater cover of $T$. ovatum was recorded in old-growth stands as compared to recovering second-growth stands on sites throughout the range, and positive correlations were found between $T$. ovatum cover and time of recovery since the last logging event (Russell, 2009; Russell \& Michels, 2010; Russell et al., 2014). In addition, increased abundance of $T$. ovatum was noted in response to distance from timber harvest edges, suggesting that the species is not only sensitive to direct disturbance, but also responds to ambient conditions created by adjacent disturbances (Russell \& Jones, 2001). Findings also suggest that level of disturbance is correlated to the cover of $T$. ovatum, with lower harvest intensities supporting greater cover of the species (Petersen, 2014).

Understory plant species have been used as forest recovery indicators in numerous forest communities, but have yet to be studied systematically in coast redwood forests (Duffy \& Meier, 1992; McLachlan \& Bazely, 2001; Scheller \& Mladenhoff, 2002; Honnay et al., 2005). The objective of this study was to analyze the abundance of individual understory species in response to logging history, with the hypothesis that shade tolerant herbaceous species would be more abundant in old-growth and mature second-growth compared to actively managed stands.

\section{Methods and Materials}

\subsection{Study Area}

The natural range of Sequoia sempervirens extends $900 \mathrm{~km}$ from the southern border of Oregon to Monterey County in central California in a narrow coastal band 12 to $32 \mathrm{~km}$ wide (Lorimer et al., 2009). In the Santa Cruz Mountains, where this study took place, topography is variable with elevations ranging from sea-level to $1154 \mathrm{~m}$ (Figure 1). A Mediterranean climate prevails with mild, rainy winters and cool, dry summers mitigated by marine fog. Average annual precipitation ranges from $70 \mathrm{~cm}$ to $147 \mathrm{~cm}$ at higher elevations. Soils consist primarily of sandstone and limestone formations, and vegetation varies on physiographic gradients between coast redwood, mixed evergreen, closed cone pine, oak wooodland, and coastal chaparral (Sawyer et al., 1999). Within coast redwood forests, S. sempervirens dominates the overstory with Pseudotsuga menziesii (Douglas-fir) as a co-odominant in some areas. Subcanopy species typically include Notholithocarpus densiflorus (tan-oak) and Umbellularia californica (California bay laurel).

Coast redwood is resistant to natural disturbances such as fire and flood, resulting in life spans exceeding 2400 years for some individuals. Coast redwood forests rarely experience natural stand replacing events, and instead follow a gap phase succession model with rare tree falls creating temporary canopy openings. Stand replacement events became prevalent in the coast redwood forest with the commencement of major timber operations in middle of the $19^{\text {th }}$ century 


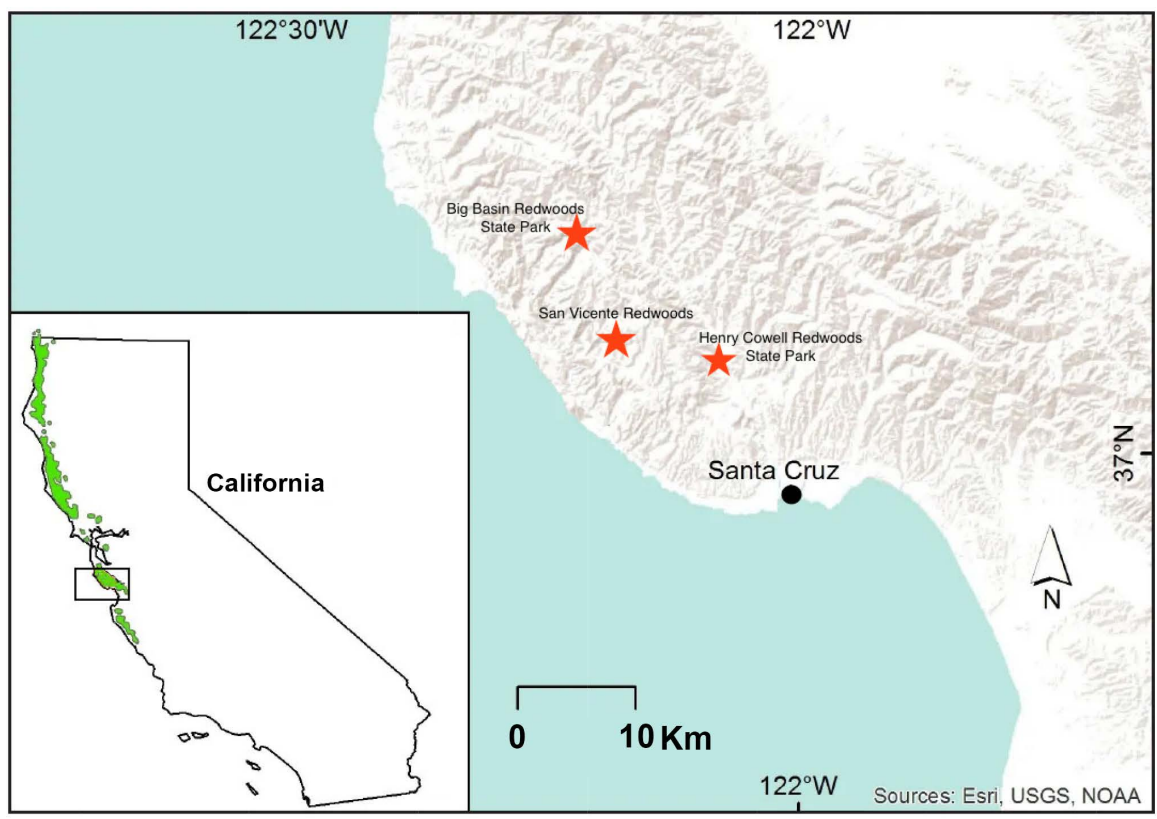

Figure 1. Location of three study areas in the Santa Cruz Mountains of California.

(Barbour et al., 2001). Much of the Santa Cruz Mountains were clear-cut by the early part of the $20^{\text {th }}$ century resulting in a patchwork of recovering second-growth stands across the landscape, with a few old-growth preserves protected in parks and preserves (Barbour et al., 2001). Timber harvesting has continued into the late $20^{\text {th }}$ and early $21^{\text {st }}$ century, primarily as small group selections on previously cutover sites.

\subsection{Sampling Strategy}

Data was collected in coast redwood forests in the Santa Cruz Mountains of California (Figure 1) between April and July of 2016 within three management treatments: 1) Previously unharvested old-growth (OG) within Big Basin State Park ( $\mathrm{n}=58) ; 2)$ Naturally recovering mature second-growth (MS) stands located in Henry Cowell Redwood State Park between 80 - 130 years old $(n=48)$; 3) Recently harvested actively-managed (AM) second-growth sites within the San Vicente Redwoods property between 0 - 45 years since harvest $(n=76)$.

A total of 182 samples were randomly selected using a GIS platform and located in the field using a hand held GPS receiver. In order to minimize edge effects, sample points were located a minimum of $100 \mathrm{~m}$ from roads, landings, timber harvest boundaries, and other significant anthropogenic features. Canopy cover (measured a with a spherical densitometer), slope, and aspect were recorded at each sample point. A $10 \mathrm{~m}$ diameter circular plot, with the center at the sample point, was used to collect data on the percent cover of all woody shrub species; the species and diameter of all live trees $(\mathrm{dbh}>4 \mathrm{~cm})$; and the percent cover of all herbaceous understory species.

Variation was detected in stand characteristics between treatments (Table 1). Understory cover, and understory species richness were significantly lower on 
Table 1. Forest structure and composition metrics across three treatments-actively managed (AM); mature second-growth (MS); and old-growth (OG) - with the three most common tree species.

\begin{tabular}{lccc}
\hline & AM & MS & OG \\
\hline Canopy cover (\%) & $83.98^{\mathrm{a}}$ & $76.35^{\mathrm{a}}$ & $81.20^{\mathrm{a}}$ \\
Shrub cover (\%) & $16.40^{\mathrm{a}}$ & $16.61^{\mathrm{a}}$ & $19.90^{\mathrm{a}}$ \\
Understory cover (\%) & $16.65^{\mathrm{a}}$ & $23.24^{\mathrm{b}}$ & $20.36^{\mathrm{b}}$ \\
Understory richness (mean/plot) & $3.31^{\mathrm{a}}$ & $4.32^{\mathrm{b}}$ & $4.08^{\mathrm{b}}$ \\
Basal area (m²/plot) & $11.27^{\mathrm{a}}$ & $19.75^{\mathrm{b}}$ & $21.99^{\mathrm{c}}$ \\
Basal area Sequoia sempervirens & $7.75^{\mathrm{a}}$ & $9.53^{\mathrm{b}}$ & $17.09^{\mathrm{c}}$ \\
Basal area Pseudotsuga menziesii & $0.38^{\mathrm{a}}$ & $0.27^{\mathrm{a}}$ & $0.26^{\mathrm{a}}$ \\
Basal area Notholithocarpus densiflorus & $3.84^{\mathrm{a}}$ & $4.32^{\mathrm{a}}$ & $3.27^{\mathrm{a}}$ \\
Density (stems/plot) & $4.81^{\mathrm{a}}$ & $3.40^{\mathrm{ab}}$ & $2.94^{\mathrm{b}}$ \\
Density Sequoia sempervirens & $3.54^{\mathrm{a}}$ & $2.41^{\mathrm{a}}$ & $2.16^{\mathrm{a}}$ \\
Density Pseudotsuga menziesii & $0.22^{\mathrm{a}}$ & $0.12^{\mathrm{a}}$ & $0.07^{\mathrm{a}}$ \\
Density Notholithocarpus densiflorus & $0.72^{\mathrm{a}}$ & $0.53^{\mathrm{a}}$ & $0.93^{\mathrm{a}}$ \\
\hline
\end{tabular}

${ }^{*}$ Different lowercase letters indicate significant differences between age-classes based of results from single factor ANOVA $(p<0.05)$.

actively-managed compared to the mature second-growth and old-growth treatments. Total basal area, and the basal area of $S$. sempervirens was progressively higher across treatments (actively-managed, mature second-growth, and oldgrowth), while stand density was successively lower. All other stand characteristic measured were statistically equivalent between treatments.

\subsection{Analytical Methods}

Non-metric multi-dimensional scaling (NMDS), using RStudio version 1.2 statistical software, was used to investigate the relationship between understory species and timber harvest history. Variation in understory species abundance between the treatments was evaluated using Permutational Multivariate Analysis of Variance (PerMANOVA), with poc-hoc Bonferroni pairwise analysis. Indicator value indices were derived from multilevel pattern indicator species analysis (ISA). One-way ANOVA (SPSS version 25) was used to compare physiographic characteristics, stand characteristics, and the abundance of species of interest between treatments. Prior to conducting ANOVA, data was tested for homogeneity using the Bartlett's Chi-Square statistic, and post-hoc analyses was conducted using the Bonferroni test for pair-wise differences between groups.

\section{Results}

Ordination of species using non-metric multiple dimensional scaling (NMDS) resulted in two convergent solutions with a stress value of 0.138 (Figure 2). 


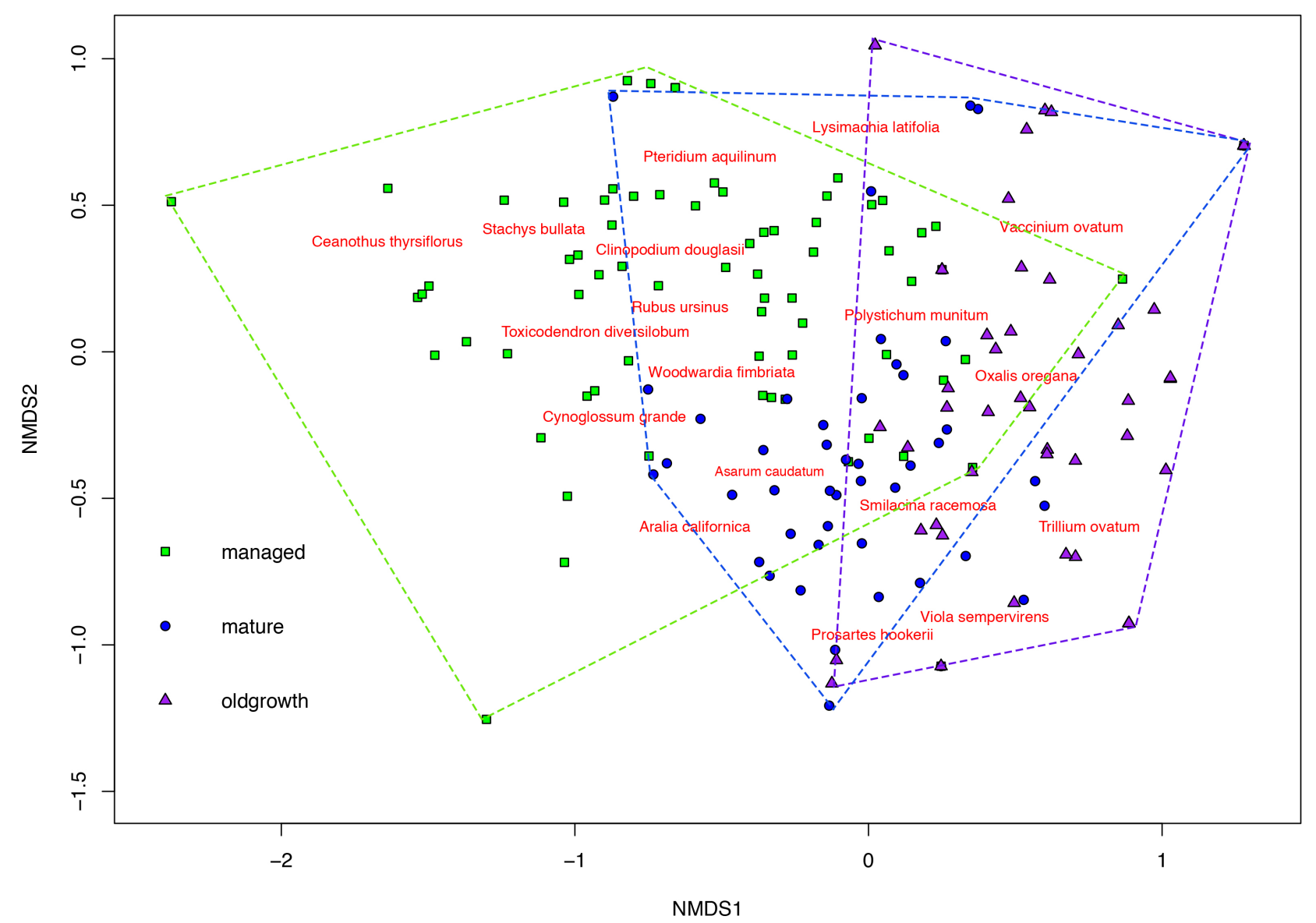

Figure 2. Ordination with non-metric multiple dimensional scaling (NMDS) for three treatments; actively-managed (AM), mature second-growth (MS), and old-growth (OG) in the coast redwood forest in the Santa Cruz Mountains of California.

Analysis with perMANOVA with Bonferroni post-hoc analysis indicated significant separation between the three treatments: actively-managed vs. mature second-growth $\left(\mathrm{R}^{2}=0.0457 ; p=0.001\right)$; actively-managed vs. old-growth $\left(\mathrm{R}^{2}=\right.$ $0.0549 ; p=0.001)$; and mature second-growth vs. old-growth $\left(\mathrm{R}^{2}=0.0451 ; p=\right.$ 0.002). The cover of T. ovatum, $V$. sempervirens, and $O$. oregana were all positively correlated along the horizontal axis NMDS1 in the direction of the mature second growth and old-growth clusters. In contrast, a negative correlation was found along the horizontal axis NMDS1 in the direction of the actively managed cluster for Ceanothus thyrsiflorus, and Stachys bullata.

Indicator species analysis (ISA) indicated that two species were associated with mature second-growth and old-growth forests ( $T$. ovatum, and Prosartes hookerii). In contrast, Stachys bullata and Ceanothus thyrsiflorus were associated exclusively with actively managed stands. In addition, nine species were associated with mature second-growth, and four were associated with mature second-growth and actively managed stands (Table 2).

Variation across treatments in the percent cover of the four species suggested as potential indicators through ISA and NMDS analyses, supported their association with mature second-growth and old-growth treatments (Figure 3). All 
Table 2. Indicator species analysis with 17 species returned out of 39 total $(n=182)$ across three treatments; actively managed (AM), mature second-growth (MS), and old-growth (OG).

\begin{tabular}{lccccc}
\hline \multicolumn{1}{c}{ Species } & Indicator value & p-value & AM & MS & OG \\
\hline Stachys bullata & 0.440 & 0.006 & $\mathrm{x}$ & & \\
Ceanothus thyrsiflorus & 0.390 & 0.002 & $\mathrm{x}$ & & \\
Pteridium aquilinum & 0.635 & 0.001 & $\mathrm{x}$ & $\mathrm{x}$ & \\
Rubus ursinus & 0.572 & 0.001 & $\mathrm{x}$ & $\mathrm{x}$ & \\
Toxicodendron diversilobum & 0.531 & 0.001 & $\mathrm{x}$ & $\mathrm{x}$ & \\
Aralia californica & 0.340 & 0.022 & $\mathrm{x}$ & $\mathrm{x}$ & \\
Oxalis oregana & 0.713 & 0.001 & & $\mathrm{x}$ & \\
Viola sempervirens & 0.388 & 0.006 & & $\mathrm{x}$ & \\
Smilacina racemosa & 0.375 & 0.001 & & $\mathrm{x}$ & \\
Asarum caudatum & 0.334 & 0.002 & & $\mathrm{x}$ & \\
Corylus cornuta & 0.280 & 0.006 & & $\mathrm{x}$ & \\
Frangula californica & 0.253 & 0.036 & & $\mathrm{x}$ & \\
Dryopteris argute & 0.243 & 0.012 & & $\mathrm{x}$ & \\
Cynoglossum grande & 0.198 & 0.041 & & $\mathrm{x}$ & \\
Heuchera micrantha & 0.198 & 0.044 & & $\mathrm{x}$ & \\
Trillium ovatum & 0.585 & 0.001 & & $\mathrm{x}$ & $\mathrm{x}$ \\
Prosartes hookerii & 0.420 & 0.003 & & $\mathrm{x}$ & $\mathrm{x}$ \\
\hline
\end{tabular}
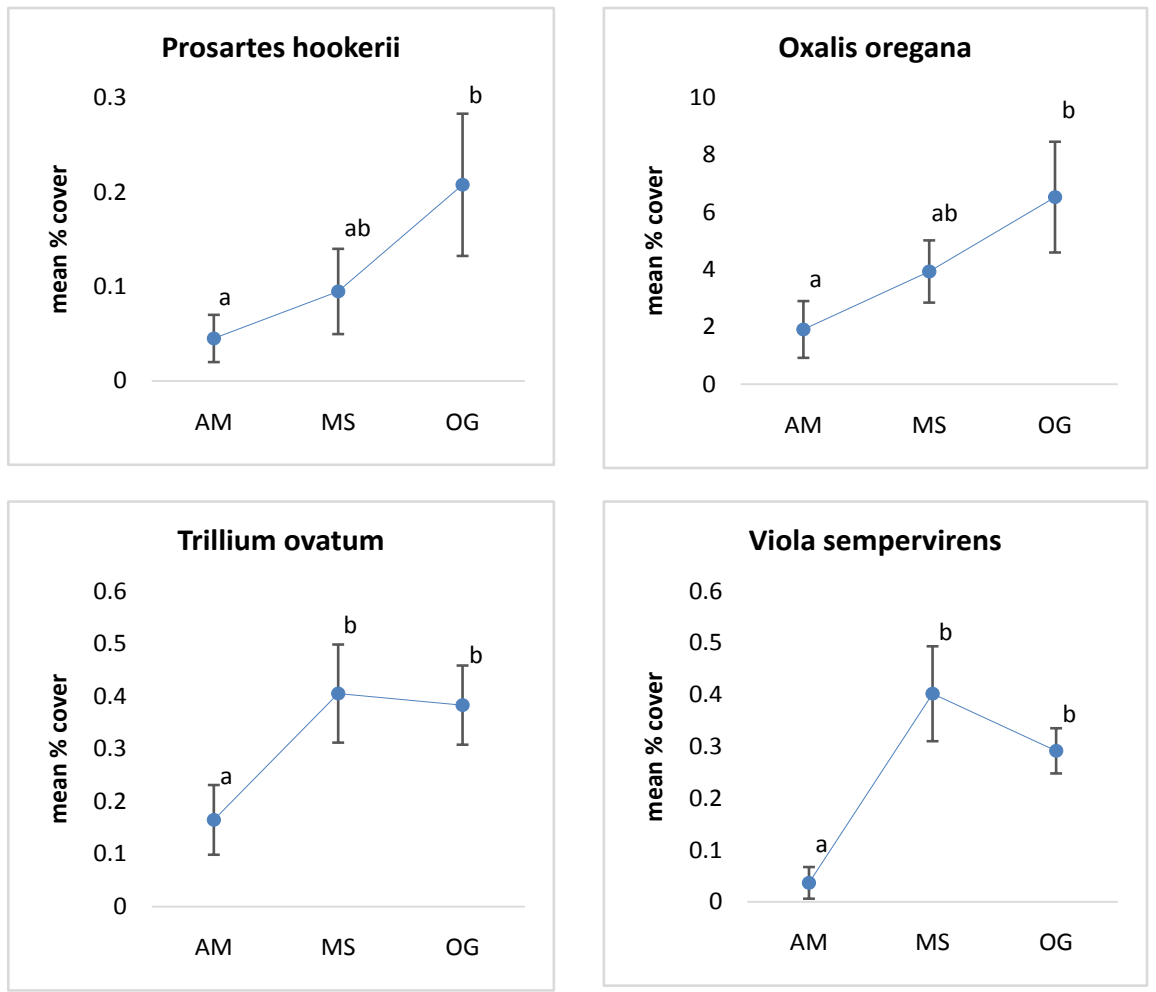

Figure 3. Average \% cover $( \pm S E)$ of four herbaceous understory species across four treatments in the Santa Cruz Mountains of California. Columns sharing the same lower case letters did not exhibit significant differences based on ANOVA results $(p>0.05)$. 
four species exhibited progressively higher percent cover from actively-managed, to mature-second-growth, and old-growth stands. The abundance of $P$. hookerii was relatively low across all treatments, and the distribution patchy, resulting in a high degree of variation. The frequency of occurrence of $T$. ovatum and $V$. sempervirens was moderate, but both species exhibited strong preferences for mature second-growth and old-growth stands. Oxalis oregana exhibited the highest frequency of occurrence of the four indicators, as well as an increases abundance across treatments.

Four non-native plants were recorded within the treatment areas including Cortaderia sp. (pampas grass), Epipactis helleborine (broadleaf helleborine), Hedera sp. (ivy), and Myosotis latifolia (forget-me-not) (Figure 4). M. latifolia and Cortaderia sp, both shade intolerant plants, were encountered exclusively in actively-managed stands, while the other two plants, Hedera sp., and E. helleborine (a shade tolerant orchid), were encountered at low levels on mature secondgrowth and old-growth sites.

\section{Discussion}

Herbaceous understory species have been found to be effective metrics of forest recovery in a variety of forest types (Duffy \& Meier, 1992; Honnay et al., 2005; Scheller \& Mladenhoff, 2002; Ellum, 2009), and the coast redwood forest appears to be no exception. Four shade tolerant herbaceous species, $O$. oregana, $P$. hookerii, T. ovatum, and $V$. sempervirens, exhibited strong associations with old-growth and mature second-growth forest conditions. The use of total understory cover, and understory richness as indicators of recovery was not supported by this research, as these measures were fairly consistent between treatments. The use of individual species that had demonstrated associations with old-forests was supported, though the selected species may vary across the geographic range of the forest type (Barbour et al., 2007).

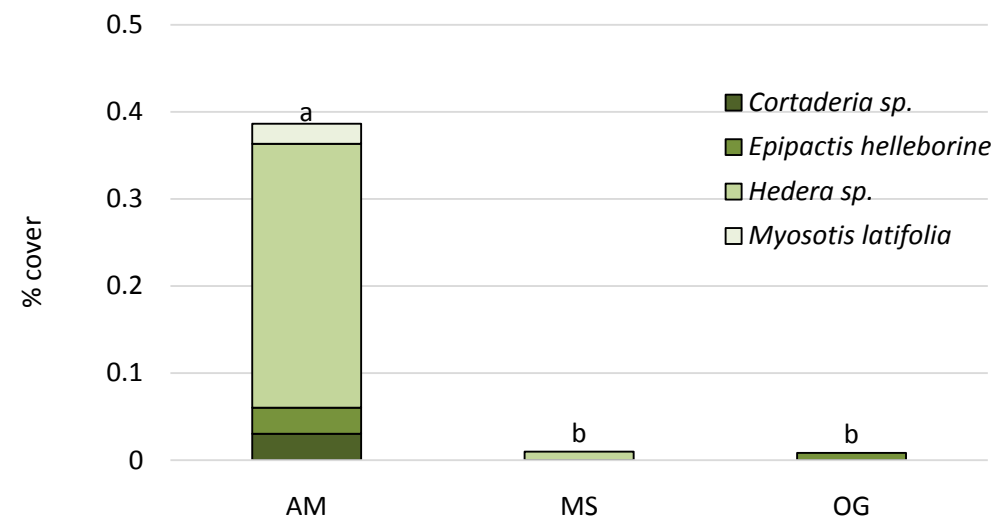

Figure 4. The mean percent cover of four non-native understory plants across three treatments; actively managed (AM), mature second-growth (MS), and old-growth (OG). Columns sharing the same lower case letters did not exhibit significant differences in combined non-native cover, based on results from single factor ANOVA $(p<0.05)$. 
Oxalis oregana is prevalent throughout the coast redwood range, and has been recorded as an indicator of coastal forest associations across the Pacific coast of North America (Steinblums et al., 1984; Lesher \& Henderson, 1992; Keyes \& Teraoka, 2014). Viola sempervirens has also been recorded as an indicator in coastal forests in North America from British Colombia to California (Lesher \& Henderson, 1992; Ceska \& Scagel, 2011). A modest body of literature supports the use of $P$. hookeri as an indicator species (Kremsater et al., 2003) and the results of this study indicate that the species has a clear affinity for old forest conditions, but low abundance and patchy distribution has reduced its' practicality as an indicator. Among the four herbaceous understory species designated as potential recovery metrics in this study, only $T$. ovatum was supported by both the NMDS and ISA analyses. In addition, a significant body of literature exists on the preference of $T$. ovatum for older forests, its sensitivity to logging, and its trajectory of recovery (Jules \& Rathcke, 1999; Kahmen \& Jules, 2005; Jenkins \& Webster, 2009). The individual growth form, size, and visibility of this species also facilitate rapid population counts, which provides a more precise measure than cover estimates. In addition, the species exhibits unique growth forms during different life stages including: cotyledon, one-leaf vegetative, three leaf vegetative (juvenile), and reproductive stages, which could lead to more nuanced analysis of T. ovatum populations (Kawano et al., 1992; Kahmen \& Jules, 2005). The presence of $T$. ovatum specimens in later life stages, for example, may suggest a lack of disturbance, as the species does not reach the reproductive stage for at least 18 years (Ream, 2011).

Non-native understory species are rare in most coast redwood forests, except in response to human disturbance (Russell \& Michels, 2010). In this study Cortaderia sp. and $M$. latifolia were only recorded in actively managed stands. Both species are shade intolerant, and require persistent, or severe, disturbance in order to persist in closed canopy forests (Lambrinos, 2001; Blair et al., 2010). Similarly, ivy species such as Hedera helix and Hedera canariensis, tend only to persist in areas of significant edge influence (Chen et al., 1992). Of the four species encountered in this study, only E. helleborine, a shade tolerant orchid, was present in old-forests, and this species poses little threat as a competitor with other understory herbs (Kolanowska, 2013). The inability of most understory exotics to persist in naturally recovering coast redwood forests was supported by studies throughout the range, with virtually all non-natives dropping out in the early stages of natural recovery (Russell \& Jones, 2001; Russell \& Michels, 2010). The closing of the canopy in the first decades of forest recovery process appears to effectively eliminate the ability for sun loving opportunists to survive. And while non-native species may not be preferred indicators of long term recovery, they may be effective as metrics for assessing disturbance in stands that are receiving repeated management inputs, such as restorative thinning (Oliver et al., 1994; O'Hara et al., 2015).

While extraordinary efforts are underway to preserve, conserve, and restore 
coast redwood forest ecosystems, simple and uniform metrics for monitoring the effectiveness of these efforts have yet to be developed. Metrics based on the cover of coast redwood associated herbaceous understory species, such as Trillium ovatum, could be effective in this regard. T. ovatum has advantages as individual counts can be accomplished readily, resulting in a density measure, which is more precise than cover estimates (Floyd, 1987). And while there is a temptation to employ more general understory metrics such as total understory cover, or understory richness, these metrics can be misleading in terms of forest recovery, as the understory community as a whole includes coast redwood associated understory species as well as generalists, early successional, and even non-native species (Chittick \& Keyes, 2007).

\section{Acknowledgements}

This project was made possible with funding from the Save-the-Redwoods League. Additional support for this project was provided by the California Department of Parks and Recreation and the Mendocino Institute. Assistance with field data collection was provided by Colin Kortman, Mary Yan, and Lacey Benson. Statistical support was provided by Alyssa Hanover.

\section{Conflicts of Interest}

The author declares no conflicts of interest regarding the publication of this paper.

\section{References}

Andersen, A. N., \& Sparling, G. P. (1997). Ants as Indicators of Restoration Success: Relationship with Soil Microbial Biomass in The Australian Seasonal Tropics. Restoration Ecology, 5, 109-114. https://doi.org/10.1046/j.1526-100X.1997.09713.x

Barbour, M. G., Evarts, J., \& Popper, M. (2001). Coast Redwood: A Natural and Cultural History. Los Olivos, CA: Cachuma Press.

Barbour, M., Keeler-Wolf, T., \& Schoenherr, A. A. (2007). Terrestrial Vegetation of California. Berkeley, CA: University of California Press. https://doi.org/10.1525/california/9780520249554.001.0001

Blair, B. C., Letourneau, D. K., Bothwell, S. G., \& Hayes, G. F. (2010). Disturbance, Resources, and Exotic Plant Invasion: Gap Size Effects in A Redwood Forest. Madroño, 57, 11-19. https://doi.org/10.3120/0024-9637-57.1.11

Busing, R. T., \& Fujimori, T. (2009). Dynamics of Composition and Structure in an Old Sequoia sempervirens Forest. Journal of Vegetation Science, 13, 785-792. https://doi.org/10.1111/j.1654-1103.2002.tb02108.x

Case, F. W., \& Case, R. B. (1997). Trilliums. Portland, OR: Timber Press.

Ceska, A., \& Scagel, A. M. (2011). Indicator Plants of Coastal British Columbia. Vancouver: University of BC Press.

Chen, J., Franklin, J. F., \& Spies, T. A. (1992). Vegetation Responses to Edge Environments in Old-Growth Douglas-Fir Forests. Ecological Applications, 2, 387-396.

https://doi.org/10.2307/1941873

Chittick, A. J., \& Keyes, C. R. (2007). Holter Ridge Thinning Study, Redwood National 
Park: Preliminary Results of A 25-Year Retrospective. In R. B. Standiford, G. A. Giusti, A. Gregory, Y. Valachovic, W. J. Zielinski, \& M. J. Furniss (Eds.), Proceedings of the redwood Region Forest Science Symposium: What Does the FUTURE hold? (pp. 271-280). Albany, CA: USDA Forest Service Gen. Tech. Rep. PSW-GTR-194.

Coelho, M. S., Fernandes, G. W., Santos, J. C., \& Delabie, J. H. C. (2009). Ants (Hymenoptera: Formicidae) as Bioindicators of Land Restoration in a Brazilian Atlantic Forest Fragment. Sociobiology, 54, 51-63.

Drever, M. C., Aitken, K. E. H., Norris, A. R., \& Martin, K. (2008). Woodpeckers as Reliable Indicators of Bird Richness, Forest Health and Harvest. Biological Conservation, 141, 624-634. https://doi.org/10.1016/j.biocon.2007.12.004

Duffy, D. C., \& Meier, A. J. (1992). Do Appalachian Herbaceous Understories Ever Recover from Clearcutting? Conservation Biology, 6, 196-201. https://doi.org/10.1046/j.1523-1739.1992.620196.x

Egli, S. (2011). Mycorrhizal Mushroom Diversity and Productivity-An Indicator of Forest Health? Annals of Forest Science, 68, 81-88. https://doi.org/10.1007/s13595-010-0009-3

Ellum, D. S. (2009). Floristic Diversity in Managed Forests: Demography and Physiology of Understory Plants Following Disturbance in Southern New England Forests. Journal of Sustainable Forestry, 28, 132-151. https://doi.org/10.1080/10549810802626431

Floyd, D. A, \& Anderson, J. E. (1987). A Comparison of Three Methods for Estimating Plant Cover. The Journal of Ecology, 75, 221-228. https://doi.org/10.2307/2260547

Gilliam, F. S. (2007). The Ecological Significance of the Herbaceous Layer in Temperate Forest Ecosystems. BioScience, 57, 845-858. https://doi.org/10.1641/B571007

Honnay, O., Jacquemyn, H., Bossuyt, B., \& Hermy, M. (2005). Forest Fragmentation Effects on Patch Occupancy and Population Viability of Herbaceous Plant Species. New Phytologist,166, 723-736. https://doi.org/10.1111/j.1469-8137.2005.01352.x

Jenkins, M. A., \& Webster, C. R. (2009). Spatial Patterning and Population Structure of a Common Woodland Herb, Trillium erectum, in Primary and Post-Logging Secondary Forests. Forest Ecology and Management, 258, 2569-2577. https://doi.org/10.1016/j.foreco.2009.09.013

Jules, E. S., \& Rathcke, B. J. (1999). Mechanisms of Reduced Trillium Recruitment along Edges of Old-Growth Forest Fragments. Conservation Biology, 13, 784-793. https://doi.org/10.1046/j.1523-1739.1999.97435.x

Kahmen, A., \& Jules, E. L. (2005). Assessing the Recovery of a Long-Lived Herb Following Logging: Trillium ovatum across a 424-Year Chronosequence. Forest Ecology and Management, 210, 107-116. https://doi.org/10.1016/j.foreco.2005.02.018

Kawano, S., OHara, M., \& Utech, F. H. (1992). Life History Studies on the Genus Trillium (Liliaceae) VI. Life History Characteristics of Three Western North American Species and Their Evolutionary-Ecological Implications. Plant Species Biology, 7, 21-36. https://doi.org/10.1111/j.1442-1984.1992.tb00239.x

Keyes, C. R., \& Teraoka, E. K. (2014). Structure and Composition of Old-Growth and Unmanaged Second-Growth Riparian Forests at Redwood National Park, USA. Forests, 5, 256-268. https://doi.org/10.3390/f5020256

Kirschbaum, C. D., \& Anacker, B. L. (2005). The Utility of Trillium and Maianthemum as Phyto-Indicators of Deer Impact in Northwestern Pennsylvania, USA. Forest Ecology and Management, 217, 54-66. https://doi.org/10.1016/j.foreco.2005.05.001

Kolanowska, M. (2013). Niche Conservatism and the Future Potential Range of Epipactis Helleborine (Orchidaceae). PLoS ONE, 8, e77352. 
https://doi.org/10.1371/journal.pone.0077352

Kremsater, L., Bunnell, F., Huggard, D., \& Dunsworth, G. (2003). Indicators to Assess Biological Diversity: Weyerhaeuse's Coastal British Columbia Forest Project. The Forestry Chronicle, 79, 590-601. https://doi.org/10.5558/tfc79590-3

Lambrinos, J. G. (2001). The Expansion History of a Sexual and Asexual Species of Cortaderia in California, USA. Journal of Ecology, 89, 88-98. https://doi.org/10.1046/j.1365-2745.2001.00524.X

Lesher, R. D., \& Henderson, J. A. (1992). Indicator Species of Forested Plant Associations on National Forests of Northwestern Washington. USDA Forest Service, Pacific Northwest Region.

Limm, E. B., Simonin, K. A., Bothman, A. G., \& Dawson, T. E. (2009). Foliar Water Uptake: A Common Water Acquisition Strategy for Plants of the Redwood Forest. Oecologia, 161, 449-459. https://doi.org/10.1007/s00442-009-1400-3

Lorimer, C. G., Porter, D. J., Madej, M. A., Stuart, J. D., Veirs Jr., S. D., Norman, S. P., \& Libby, W. J. (2009). Presettlement and Modern Disturbance Regimes in Coast Redwood Forests: Implications for the Conservation of Old-Growth Stands. Forest Ecology and Management, 258, 1038-1054. https://doi.org/10.1016/j.foreco.2009.07.008

Loya, D. T., \& Jules, E. S. (2008). Use of Species Richness Estimators Improves Evaluation of Understory Plant Response to Logging: A Study of Redwood Forests. Plant Ecology, 194, 179-194. https://doi.org/10.1007/s11258-007-9283-Z

Mcclelland, B. R., \& Mcclelland, P. T. (1999). Pileated Woodpecker Nest and Roost Trees in Montana: Links with Old-Growth and Forest "Health". Wildlife Society Bulletin, 27, 846-857.

McLachlan, S., \& Bazely, D. (2001). Recovery Patterns of Understory Herbs and Their Use as Indicators of Deciduous Forest Regeneration. Conservation Biology, 15, 98-110. https://doi.org/10.1111/j.1523-1739.2001.98145.x

Meier, A .J., Bratton, S. P., \& Duffy, D. C. (1995). Possible Ecological Mechanisms for Loss of Vernal-Herb Diversity in Logged Eastern Deciduous Forests. Ecological Applications, 5, 935-946. https://doi.org/10.2307/2269344

Noss, R. F. (1999). The Redwood Forest: History, Ecology, and Conservation of the Coast Redwoods. Washington DC: Island Press.

O’Hara, K. L., Narayan, L., \& Cahill, K. G. (2015). Twelve-Year Response of Coast Redwood to Precommercial Thinning Treatments. Forest Science, 61, 780-789.

https://doi.org/10.5849/forsci.14-178

Oliver, W. W., Lindquist, J. L., \& Strothmann, R. O. (1994). Young-Growth Redwood Stands Respond Well to Various Thinning Intensities. Western Journal of Applied Forestry, 9, 106-112. https://doi.org/10.1093/wjaf/9.4.106

Pander, J., \& Geist, J. (2013). Ecological Indicators for Stream Restoration Success. Ecological Indicators, 30, 106-118. https://doi.org/10.1016/j.ecolind.2013.01.039

Petersen, A. K. (2014). Coast Redwood Community Structure and Composition Following Selective-Harvest: A Case Study of Byrne-Milliron Forest. Master's Theses, San Jose, CA: San Jose State University. http://scholarworks.sjsu.edu/etd theses/4437/

Ream, T. (2011). Life History and Demography of Trillium ovatum Pursh. (Liliaceae) in Western Montana. Doctoral Dissertation, Missoula, MT: The University of Montana.

Runkle, J. R. (1982). Patterns of Disturbance in Some Old-Growth Mesic Forests of Eastern North America. Ecology, 63, 1533-1546. https://doi.org/10.2307/1938878

Russell W., \& Jones, C. (2001). The Effects of Timber Harvesting on the Structure and Composition of Adjacent Old-Growth Coast Redwood Forest, California, U.S.A. Land- 
scape Ecology, 16, 731-741. https://doi.org/10.1023/A:1014486030462

Russell W., \& Michels, K. (2010). Stand Development on a 127-Yr Chronosequence of Naturally Regenerating Sequoia sempervirens (Taxodiaceae) Forests. Madroño, 57, 229-241. https://doi.org/10.3120/0024-9637-57.4.229

Russell, W. (2009). The Influence of Timber Harvest on the Structure and Composition of Riparian Forests in the Coastal Redwood Region. Forest Ecology and Management, 257, 1427-1433. https://doi.org/10.1016/j.foreco.2008.12.014

Russell, W., Sinclair, J., \& Michels, K. H. (2014). Restoration of Coast Redwood (Sequoia sempervirens) Forests Through Natural Recovery. Open Journal of Forestry, 4, 106-111. https://doi.org/10.4236/ojf.2014.42016

Sawyer, J. O., Sillett, S. C., Libby, W. J., Dawson, T. E., Popenoe, J. H., Largent, D. L. et al. (1999). Redwood Trees, Communities. In The Redwood Forest: History, Ecology, and Conservation of the Coast Redwoods (p. 81).

Scheller, R. M., \& Mladenoff, D. J. (2002). Understory Species Patterns and Diversity in Old-Growth and Managed Northern Hardwood Forests. Ecological applications, 12, 1329-1343. https://doi.org/10.1890/1051-0761(2002)012[1329:USPADI]2.0.CO;2

Steinblums, I. J., Froehlich, H. A., \& Lyons, J. K. (1984). Designing Stable Buffer Strips for Stream Protection. Journal of Forestry, 82, 49-52.

Van Pelt, R., \& Franklin, J. F. (2000). Influence of Canopy Structure on the Understory Environment in Tall, Old-Growth, Conifer Forests. Canadian Journal of Forest Research, 30, 1231-1245. https://doi.org/10.1139/x00-050 